\title{
Health Issues of the Tribal Populace of Forest
}

\author{
Thulasi G. Pillai*
}

Department of Forest Health Division, Kerala Forest Research Institute, Peechi, Thrissur, Kerala, India

"Corresponding author: Thulasi G. Pillai, Department of Forest Health Division, Kerala Forest Research Institute, Peechi, Thrissur - 680653, Kerala, India. Tel: +914872690100; Email:thulasigpillai@gmail.com

Citation: Pillai TG (2018) The Tribal Populace of Forest. Curr Trends Forest Res: CTFR-112. DOI: 10.29011/ CTFR-102.100012

Received Date: 04 April, 2018; Accepted Date: 10 April, 2018; Published Date: 16 April, 2018

\section{Abstract}

The earlier inhabitants of the land are called as tribals. They are very much isolated from the other population due to differences in language, culture, tradition, and lifestyle. Their health status often remains poor due to many reasons- poverty, malnutrition, lack of awareness, unaffordability to medication, lack of availability of proper medication etc. More research, studies and interventions are needed in this are for their upliftment.

Keywords: Forest; Health; India; Poverty; Research; Tribals

\section{Introduction}

Forest, one of the most beautiful part of our planet earth provides shelter for a large number of human population. Forest cover $31 \%$ of world's land surface [1]. In India, the second most populous country in the world, the concept of tribe emerged in India during the time of British [2]. Their life is very much in tune with nature being part of the ecosystem. Also, they are very much prudent in the use of natural resources. This short note focus on tribals in India. India is source of more than half the world tribal population. Tribals of India are known to be autochthonous people of the land [2]. The forest policies during the British colonial period and post independent development activities have destroyed the self-sufficiency of the tribal people. Their calm life got affected in many ways. The geographical factors exert some influence on them. They have distinctive health problems mainly governed by their habitat, difficult terrains and ecologically variable niches [2]. The health, nutrition and medico-genetic problems are unique and present a formidable challenge for which approximate solutions have to be found by planning and evolving relevant studies. Some tribal communities are in the verge of extinction [3].

\section{Health Issues in Tribal Community}

They have distinctive health problems mainly influenced by habitat, difficult terrains and ecologically variable niches. The health issues among these communities had always presented great challenge. Genetic diseases like Sickle cell anaemia, G-6-PD red cell enzyme deficiency are quiet common among tribals [2]. Infectious diseases like malaria, tuberculosis, influenza, dysentery are another important group of disease. Lack of sanitation and awareness, poverty, malnutrition, nutrient deficiency add to the difficulty. Nutritional anaemia is very profound among tribal women.

Need of intervention research, environmental sanitation. $90 \%$ of tribal people are not aware about their rights and freedom, job opportunities and educational schemes. levels of health deprivation are always experienced by the poorest and most marginalised population groups [4]. Scheduled tribes have been recognised as a distinct community in India through a constitutional mandate formulated in 1950[5]. Some of them live isolated, living in remote forest forest and hilly areas. High rate of maternal and child mortality The inadequate health infrastructure for these health needs is also a major factor. Apart from genetic disorders and communicable diseases these group of populations are also prone to lifestyle related diseases like type 2 diabetes, hypertension and soon [6]. Health conditions in tribals present an alarming situation, as such it is difficult to provide satisfactory health facilities in tribal areas [7]. Studies, research, awareness in this area are need of the hour. It is worthwhile to study more in this area where a lot of contribution can be done for the needy. Hope the status of these group of population, our brethren will be uplifted in the near future.

\section{References}

1. Earth Policy Institute. 2012.Rutgers University.

2. Salil Basu (2000) Dimensions of Tribal Health in India. Health and population-Perspectives and Issues 23: 61-70.

3. Verma IC, Puri RK (1978) Medico-Genetic Problems of primitive tribal communities. Medical Genetics in India. 2. Auroma Enterprises, Puducherry. 
Citation: Pillai TG (2018) The Tribal Populace of Forest. Curr Trends Forest Res: CTFR-112. DOI: 10.29011/ CTFR-102. 100012

4. Willis R, Stephens C Nettleton C (2004) The right to health of indigenous peoples. Report of a conference held at the London School of Hygiene and Tropical medicine. London: Health Unlimited.

5. India Ministry of Tribal affairs (2004) The national tribal policy (draft). New Delhi: India Ministry of tribal affairs.
6. Sachdev B (2011) Community based study on incidence of type 2 diabetes and hypertension among nomad tribal population of Rajasthan, India. Int J Sci and Nature 2: 296-301.

7. Nagda BL (2004) Tribal population and health in Rajasthan stud Tribes. Tribals 2: 1-8. 